№ 977. [Regulations on accreditation of educational programs, according to which training of higher education seekers is carried out: approved by the order of the Ministry of Education and Science of Ukraine 11.07.2019. No. 977]. Available at: https:// zakon.rada.gov.ua/laws/show/z0880-19 (Accessed 22 Jan. 2021). [in Ukrainian].

5. Profesiinyi standart "Vchytel pochatkovykh klasiv zakladu zahalnoi serednioi osvity": zatverdzhenyi nakazom Ministerstva sotsialnoi polityky Ukraiiny vid 10.08.2018 r. № 1143. [Professional standard "Primary School Teacher of the Institution of General Secondary Education": approved by the order of the Ministry of Social Policy of Ukraine 10.08.2018. No. 1143]. Available at: https:/ /zakon.rada.gov.ua/rada/show/v1143732-18 (Accessed 19 Jan. 2021). [in Ukrainian].
6. Sardalova, E. Navishcho vchyteliam molodshykh klasiv profesiinyi standart [Why do Primary School Teachers Need Professional Standard]. Available at: https://www.radiosvoboda.org/a/navishcho-profesiinyistandart-molodsha-shkola/29454318.html. (Accessed 20 Jan. 2021). [in Ukrainian].

7. Starovoit, L. Ya. (2000). Osoblyvosti orhanizatsii bahatostupenevoho navchannia u vyshchomu profesiinomu uchylyshchi [Peculiarities of Organization of Multistage Education in Higher Vocational School]. Extended abstract of candidate's thesis. Kyiv, 20 p. [in Ukrainian].

8. Shkvyr, O. L. (2018). Stupeneva pidhotovka maibutnikh uchyteliv pochatkovoi shkoly do provedennia pedahohichnykh doslidzhen: monohr [The gradual preparation of future primary school teachers for pedagogical research]. Zhytomyr, 500 p. [in Ukrainian].

Стаття надійшла до редакції 30.11.2020

УДК 378.018.8:373.5.011.3-051]:614]

DOI:

Дарія Возносименко, доктор філософіï, дочент кафедри вищої математики та методики навчання математики Уманського державного педагогічного університету імені Павла Тичини

\title{
ПРАКТИЧНА ПІДГОТОВКА СТУДЕНТІВ ДО ЗДОРОВ'ЯЗБЕРЕЖЕННЯ УЧНІВ НА УРОКАХ МАТЕМАТИКИ ЯК ВАЖЛИВА СКЛАДОВА ОСВІТНЬОГО ПРОЦЕСУ
}

У статті висвітлено актуальність проблеми підготовки майбутніх учителів математики до здоров'язбереження учнів. Розглянуто, шуо практична підготовка майбутнього вчителя математики до здоров 'язбережувальної діяльності-це невід 'ємний компонент фахової підготовки, яка передбачає оволодіння студентами навичками, уміннями та способами організації майбутньої професійної діяльності. Педагогічна практика є однією із ключових форм набуття студентами суб'єктного практичного досвіду педагогічної здоров 'язбережувальної діяльності. Наведено приклади завдань для студентів під час проходження практики, які спрямовані на розвиток здоров'язбережувальної компетентності учнів. Зазначено, щуо розробка та використання вправ здоров 'язбрежувального змісту сприяє розвитку інтересу учнів до предмету, i насамперед формуванню здров 'язбрежувальної компетентності учнів.

Ключові слова: здоров'язбереження; підготовка вчителя математики; педагогічна практика, здоров'язбережувальні технологї; практична підготовка.

תim. 12.

Dariia Voznosymenko, Doctor of Philosophy Sciences, Associate Professor of Higher Mathematics and Methods of Teaching Mathematics Department Pavlo Tychyna Uman State Pedagogical University

\section{PRACTICAL PREPARATION OF STUDENTS FOR STUDENTS HEALTH IN MATHEMATICS LESSONS AS AN IMPORTANT COMPONENT OF THE EDUCATIONAL PROCESS}

The article highlights the urgency of the problem of preparing future teachers of mathematics for the health of students. Based on the analysis of the scientific literature, it was found that a significant place in the problem of health care of the younger generation is given, above all, to teachers who have modern pedagogical technologies, plans and organizes their activities taking into account the priorities of preserving and strengthening the health of all objects of the educational process. It is noted that one of the main factors that will help solve the problem of improving the quality of mathematical training in schools and institutions of higher education is a highly qualified modern mathematics teacher who can not only qualitatively transfer knowledge, but also motivate, interest, create 


\section{ПРАКТИЧНА ПІДГОТОВКА СТУДЕНТІВ ДОЗДОРОВ'ЯЗБЕРЕЖЕННЯ УЧНІВ НА УРОКАХ МАТЕМАТИКИ ЯК ВАЖЛИВА СКЛАДОВА ОСВІТНЬОГО ПРОЦЕСУ}

conditions for creative, active cognitive activity, as well as able to preserve and strengthen the health of students in the process of learning mathematics.

It is considered that the practical preparation of the future teacher of mathematics for health activities is an integral component of professional training, which involves students mastering the skills, abilities and ways of organizing future professional activities. It is noted that pedagogical practice occupies an important place in the system of professional training of mathematics teachers. Pedagogical practice is an integral part of the preparation of mathematics teachers for the health of students and one of the key forms of students gaining subjective practical experience of pedagogical health activities. It is concluded that such activities allow the student to realize himself in the role of a teacher who is able to form in students a conscious attitude to their own health.

Keywords: health; mathematics teacher training; pedagogical practice; health technologies; practical training.

A ктуальність. Нині проблема здоров'язбереження набуває глобального масштабу. Вона посідає сьоме місце серед загроз планетарного масштабу (загроза світової війни, екологічні катаклізми, нерівність економічних відносин в різних країнах світу, демографічна загроза, нестача природних ресурсів, наслідки науково-технічного прогресу, проблема здоров'язбереження людства).

До того ж, стан здоров'я нації виступає показником духовного, соціально-економічного та медико-біологічного рівня добробуту цивілізованої країни. Означена проблема спонукає до пошуку нових шляхів і1ї розв'язання у наукових дослідженнях з питань збереження здоров'я учнів закладів загальної середньої освіти України. Актуальність проблеми формування в учнів відповідального ставлення до свого здоров'я та здоров'я навколишніх як найвищої цінності, відображено у таких нормативних документах: Національна доктрина розвитку освіти України у XXI ст., закони України "Про освіту”, "Про повну загальну середню освіту”, "Про вищу освіту”, Національна стратегія розвитку освіти в Україні, Національна стратегія з оздоровчої рухової активності в Україні на період до 2025 р. "Рухова активність - здоровий спосіб життя - здорова нація”, Концепція “Нова українська школа” тощо.

Згідно з Національною доктриною розвитку освіти в Україні, передбачено, що держава повинна стимулювати прагнення молоді до здорового способу життя, а основним завданням визначено виховання людини в дусі відповідального ставлення до власного здоров'я і здоров'я навколишніх [7].

У такому разі значне місце у проблемі здоров'язбреження підростаючого покоління відводиться, передовсім вчителю, який володіє сучасними педагогічними технологіями, сплановує і організовує свою діяльність, враховуючи пріоритети збереження та зміцнення здоров'я підростаючого покоління у процесі навчання.

Постановка проблеми і ступінь дослідження. Питання, пов’язанні з проблемою формування здорового способу життя учнів і молоді, висвітлено у працях Г. Апанасенка, В. Бабича, Л. Ващенко, М. Гончаренко, М. Гриньової, В. Кузя, С. Кириленко,В. Оржеховської,В. Сухомлинського, К. Ушинського, Н. Урум та ін. Культура здоров'я особистості була об'єктом дослідження низки науковців, серед яких В. Горащук, О. Дубогай, В. Колбанов, Л. Татарнікова, Е. Вайнер та ін.

Підготовка майбутніх учителів до здоров'язбережувальної діяльності є предметом наукових досліджень вітчизняних та зарубіжних учених, зокрема Н. П'ясецької [10], Г. Жари [4], I. Щербини [12], Т. Книш [5], О. Адєєвої [1], Н. Урум [11], Т. Осадченко [9] та інших.

Метою статті $\epsilon$ характеристика особливостей практичної підготовки студентів до здоров'язбереження учнів на уроках математики шляхом застосування в освітньому процесі здоров'язбережувальних технологій.

Виклад основного матеріалу. На сьогодні математична освіта в Україні стоїть перед низкою змістових, організаційних та ціннісних викликів. Це стосується як шкільної, так вищої освіти. Одним 3 основних факторів, що сприятиме розв'язанню проблеми підвищення якості математичної підготовки в школах та ЗВО, є висококваліфікований сучасний вчитель математики, здатний не тільки якісно передавати знання, а й мотивувати, зацікавлювати, створювати умови для творчої, активної пізнавальної діяльності, а також здатний до збереження та зміцнення здоров'я учнів у процесі навчання математики.

Одним із аспектів удосконалення фахової підготовки майбутніх учителів математики в педагогічному університеті $є$ практична підготовка студентів до впровадження компетентнісного підходу в систему шкільної освіти. Практична підготовка майбутніх учителів математики - це невід'ємний компонент фахової підготовки, що передбачає оволодіння студентами навичками, уміннями та способами організації майбутньої професійної діяльності.

Як зазначено в новій програмі з математики для учнів 5-9 класів, наскрізна лінія “Здоров’я і безпека” в курсі математики реалізується через 


\section{ПРАКТИЧНА ПДГОТОВКАСТУДЕНТІВ ДОЗДОРОВ'ЯЗБЕРЕЖЕННЯ УЧНІВ НА УРОКАХ МАТЕМАТИКИ ЯК ВАЖЛИВА СКЛАДОВА ОСВІТНЬОГО ПРОЦЕСУ}

завдання $з$ реальними даними про безпеку й охорону здоров'я (текстові завдання, пов'язані із середовищем дорожнього руху, рухом пішоходів і транспортних засобів, відсотковими обчисленнями й графіками, що стосуються чинників ризику). Особливо важливий аналіз причин ДТП, пов'язаних із перевищенням швидкості. Варто звернути увагу на проблеми, пов'язані з ризиками для життя і здоров'я, при вивченні основ математичної статистики. Розв'язання проблем, знайдених з “ага-ефектом”, розгляд красивих геометричних конструкцій, пошук оптимальних методів розв'язування задач тощо, здатні викликати в учнів чимало радісних емоцій [8].

Як розглянуто нами у роботі [2], підготовку вчителя до реалізації цієї наскрізної лінії у школі слід розпочинати 3 перших років навчання студентів у педагогічному університеті під час як аудиторної, так і позааудиторної роботи. Автором розроблено методичні рекомендації щодо підготовки майбутніх учителів математики до реалізації наскрізної лінії ключових компетентностей “Здоров’я і безпека”.

У системі професійної підготовки учителів математики важливе місце посідає педагогічна практика, що є невід'ємною складовою підготовки вчителя математики та однією із ключових форм набуття студентами суб'єктного практичного досвіду педагогічної діяльності. Певного досвіду студенти набувають у процесі квазіпрофесійної педагогічної діяльності на заняттях із методичних дисциплін, а педагогічна практика дає змогу розширити цей досвід в умовах реальних закладів освіти [3].

Залежно від навчальних планів 3ВО, види педагогічних практик у системі підготовки майбутніх учителів математики варіюються, зокрема, навчальна педагогічна практика проходить на другому або третьому курсі, як правило, на четвертому курсі, педагогічна виробнича (на четвертому курсі бакалаврату та у магістратурі).

Педагогічна практика доповнюе і збагачує теоретичну підготовку студентів, створює умови для вироблення в них умінь та навичок, необхідних для навчання учнів математики, зокрема, до реалізації наскрізної лінії “Здоров”я та безпека”.

Головною метою навчальної педагогічної практики $є$ ознайомлення студентів із системою освітньої, позакласної та позашкільної роботи вчителя математики і школи загалом; формування уміння конструювати і організовувати окремі елементи процесу навчання математики; вивчати досвід навчальної, виховної та позакласної роботи вчителів-предметників і класних керівників у колективах учнів 5-9 класів.
Відповідно до цього, основними завданнями цього виду практики $є$ :

- надбання і розвиток навичок з організації самостійного проведення навчальної та виховної роботи з учнями $з$ урахуванням їхніх вікових особливостей;

- розвиток практичних умінь із проведення навчальної та виховної роботи з класом;

- розробка матеріалів та проведення 1-2 пробних уроків із математики;

- участь у проведенні індивідуальних і групових додаткових занять із учнями, що відстають у навчанні, та тими, хто має високий рівень навчальних досягнень.

Під час навчальної педагогічної практики ми пропонуємо студентам розробити пробний урок 3 математики з використанням здоров'язбережувальних технологій, а також дидактичні засоби навчання (підбір валеологічних задач до конкретної тематики, фізкультхвилинок, сміхових вправ).

Провідною, 3 точки зору підготовки майбутнього вчителя математики до здоров'язбереження учнів, $\epsilon$ виробнича педагогічна практика. Ї̈̈ мета - оволодіння методиками здійснення освітньої діяльності та формування вмінь і навичок самостійного проведення освітньої та позакласної роботи 3 учнівськими колективами в основній школі (5-9-й класи), спонукання студентів до професійного самовдосконалення.

Проходження виробничої педагогічної практики передбачає виконання студентомпрактикантом низки завдань, а також одночасне виконання функцій практиканта, учителяпредметника та класного керівника. Це, зі свого боку, створює всі необхідні умови для здоров'язбереження учнів на уроках математики. Так, під час проходження педагогічної практики студенти мають можливість розробити планиконспекти уроків математики, позакласних заходів, гурткових занять, одним із завдань яких $\epsilon$ орієнтування учасників освітнього процесу на здоровий спосіб життя, профілактику шкідливих звичок та попередження конфліктних ситуацій у соціумі. У процесі такої діяльності майбутні вчителі знайомляться 3 методами і способами впровадження здоров'язбережувальних технологій на уроках математики [3].

Одним із ключових завдань, які ми пропонуємо студентам, $\epsilon$ розробка та проведення уроків математики з використанням здоров'язбережувальних технологій (зокрема, фізкультхвилинок, сміхової та кольоротерапії, хвилинок здоров'я, вправ валеологічного та здоров'язбережувального змісту і т.д). 


\section{ПРАКТИЧНА ПДГОТОВКА СТУДЕНТІВ ДОЗДОРОВ'ЯЗБЕРЕЖЕННЯ УЧНІВ НА УРОКАХ МАТЕМАТИКИ ЯК ВАЖЛИВА СКЛАДОВА ОСВІТНЬОГО ПРОЦЕСУ}

Наведемо для прикладу фрагмент розробленої вправи для учнів 6-го класу на уроці математики під час вивчення теми “Основна властивість пропорції’.

Вправа “Молоко - джерело здоров'я".

Мета. Звернути увагу учнів на важливість вживання вітамінів для росту та розвитку дитячого організму; формувати в учнів вміння розв'язувати задачі на основну властивість пропориіï; застосувати набуті знання для розв'язування прикладних задач.

\section{Інструкція}

3 давніх пір існує думка, що коров'яче молоко є джерелом здоров'я. Вже тоді люди замислювалися над тим, які вітаміни містяться в молочі. Не знаючи фізичних властивостей, хімічного складу, вони називали його “соком життя” або “білою кров'ю”.

У коров'ячому молоці зібрані всі необхідні біологічні речовини, здатні задовольняти фізіологічні потреби живого організму. Про ие знають навіть герої улюблених мультфільмів https://www.youtube.com/watch? $v=x f g H h c p p H r 8$

I вирішив кіт довести корисність молока на прикладі задачі:

Задача

У 250 мл молока корови Мурки міститься близько 300 мг кальцію, скільки отримає кальцію Шарик, якщо вип'є 1л молока?

\section{Обговорення}

1. Який вітамін міститься в молоці $i$ молочних продуктах?

2. Для чого його необхідно вживати?

3. Які з продуктів є джерелами вітаміну D?

4. Які інші вітаміни вам відомі, крім Са? Задача

Мінімальний необхідний 12-річному школяру об'єм молочних продуктів відноситься до всього об'єму рідини, щуо випивається за день, як 3 : 20. Скільки молока, кефіру або ряжанки повинен випивати шестикласник, якщо усього за день у його раціон входить 2 літра рідини.

\section{Підсумки}

Підводимо учнів до висновку, щео для здорового розвитку організму необхідно вживати продукти, багаті на вітаміни, зокрема коров'яче молоко.

\section{Інформаційна скринька}

Розглянемо корисні властивості, які має коров'яче $i$ козяче молоко для дітей. Молоко містить вітаміни $A, B, B 2, C$, мінеральні речовини, легкозасвоювані білки, жири $i$ вуглеводи. Крім усього іншого, в ньому міститься дуже багато кальц̧ію, щзо такий корисний зростаючим дітям.
Молоко для дітей просто незамінне, адже в ньому містяться такі амінокислоти, як метіонін і лізин. Саме ці амінокислоти беруть участь у формуванні антитіл, ферментів травлення та інсуліну. Також метіонін, амінокислота, яка міститься в молочі, зв'язуе i виводить важкі метали з організму дитини.

Загалом у молоці міститься понад 200 різних органічних і мінеральних речовин, які позитивно впливають на розвиток дитячого організму. Молоко для дітей $i$ дорослих корисно також тим, щяо добре підвищує рівень заліза в крові, $i$ з його допомогою можна лікувати гастрит з підвищеною кислотністю, захворювання дванадиятипалої кишки, виразку шлунка. Дуже добре молоко сприяє лікуванню захворювань печінки. Як не дивно, молоко для дітей може принести ще користь $y$ стоматологіï. Воно допомагае при профілактиці захворювання карієсу. Молоко насичує зуби дітей кальиієм і знижує їх чутливість до його збудників.

Дефіцуит кальичію, який дитина отримує з молока, може призвести в майбутньому до порушення розвитку кісткової тканини. Такі порушення, зі свого боку спричиняють розвиток остеопорозу, деформацій кісток $і$ переломів.

Використання таких вправ сприяє розвитку інтересу учнів до предмету, і насамперед формуванню здров'язбрежувальної компетентності учнів.

Ще одним елементом у практичній підготовці майбутнього вчителя математики до здоров'язбережувальної діяльності є здійснення валеологічного самоаналізу та аналізу проведеного уроку. У процесі валеологічного аналізу уроку математики в 3ЗСО студентам слід визначити такі фактори його побудови, які формують фізичне, соціальне, психічне та духовне здоров’я учнів: позитивну мотивацію діяльності; урахування індивідуальних стилів та можливостей навчання учнів; розв'язання математичних вправ, що забезпечують розвиток валеологічного мислення учнів; створення належних умов для повноцінної і здоров'язбережувальної діяльності учнів; рефлексивність уроку.

Під час проходження педагогічної практики студентам створюються всі умови для:

- дослідження умов навчання та виховання учнів у $33 \mathrm{CO}$;

- проведення валеологічного аналізу організації уроків математики;

- вивчення закономірностей впливу умов навчання і виховання на працездатність і успішність учнів; 


\section{ПРАКТИЧНА ПІДГОТОВКА СТУДЕНТІВ ДОЗДОРОВ'ЯЗБЕРЕЖЕННЯ УЧНІВ НА УРОКАХ МАТЕМАТИКИ ЯК ВАЖЛИВА СКЛАДОВА ОСВІТНЬОГО ПРОЦЕСУ}

- оволодіння оздоровлювальними технологіями навчання;

- проведення оцінювання фізичного розвитку та рівня здоров'я учнів [6, 2].

Висновки. Проведення уроків та позакласних заходів здоров'язбережувального змісту дає можливість студенту реалізувати себе в ролі вчителя, здатного сформувати в учнів свідоме ставлення до власного здоров'я. Отже, реалізація такої діяльності під час педагогічної практики сприяє: формуванню у студентів знань, навичок і умінь, необхідних для пропагування здорового способу життя, збереження й зміцнення як власного здоров'я, так і здоров'я учнів; формуванню умінь використовувати отримані знання валеологічного змісту у повсякденному житті; оволодінню навичками розвитку в учнів валеологічного мислення та культури засобами математики.

Перспективи подальших досліджень. Перспективи подальших досліджень полягають у розробці методичних засад підготовки майбутніх учителів математики до екологічного виховання учнів на уроках математики.

\section{ЛІТЕРАТУРА}

1. Адєєва О. В. Підготовка майбутніх учителів до валеологічного виховання учнів загальноосвітніх навчальних закладів: дис. ... канд. пед. наук: 13.00.04. Одеса, 2008. 210 с.

2. Возносименко Д. Підготовка майбутніх вчителів математики до реалізації наскрізної лінії ключових компетентностей “Здоров’я і безпека”. Проблеми підготовки сучасного вчителя. Умань, 2017. Вип. 16. C. 106-112.

3. Возносименко Д. А. Підготовка майбутніх учителів математики до забезпечення валеологічного супроводу навчання учнів основної школи : дис. ... док. філос.. : 011. Умань, 2020.376 с.

4. Жара Г. І. Підготовка майбутніх учителів до формування в учнів валеологічних понять на засадах міжпредметних зв'язків шкільних природничих курсів: дис. ... канд. пед. наук: 13.00.04. Київ, 2009. 283 с.

5. Книш Т. В. Валеологічна підготовка майбутніх вихователів дошкільних закладів освіти: дис. ... канд. пед. наук: 13.00.04. Луцьк, 2001. 211 с.

6. Коробова І. Реалізація індивідуального підходу до формування методичної компетентності майбутніх учителів фізики. Наукові записки Серія: Проблеми методики фізико-математичної $і$ технологічної освіти. Кіровоград, 2013. Вип. 4(1). С. 155-159.

7. Національна доктрина розвитку освіти: Указ Президента України від 17 квітня 2002 року № 347/2002. URL: htpp://www.kmu.gov.ua/control/uk/publis

8. Оновлення програм для базової загальної середньої освіти URL: https://www.ed-era.com/mon59/ (Датазвернення 15.01.2021)

9. Осадченко Т. М. Підготовка майбутнього вчителя до створення здоров'язбережувального середовища початкової школи: дис. ... канд. пед. наук: 13.00 .04 . Житомир, 2017.251 с.

10. П'ясецька Н. А. Формування валеологічної культури майбутніх учителів у вищих закладах освіти I II рівнів акредитації: дис. ... канд. пед. наук: 13.00.04. Київ, 2004. 223 c.

11. Урум Н. С. Підготовка майбутніх вчителів до забезпечення здорового способу життя молодших школярів: дис. ... канд. пед. наук: 13.00.04. Київ, 2008. $213 \mathrm{c}$.

12. Щербина I. Ю. Педагогічні умови підготовки майбутніх учителів до здоров' язберігаючого навчання учнів у загальноосвітній школі: автореф. дис. ... канд. пед. наук: 13.00.04. Черкаси, 2017. 20 с.

\section{REFERENCES}

1. Adeeva, O.V. (2008). Pidhotovka maybutnikh uchyteliv do valeolohichnoho vykhovannya uchniv zahalnoosvitnikh navchalnykh zakladiv [Preparation of future teachers for valeological education of students of secondary schools].Candidate's thesis. Odessa, 210 p.[in Ukrainian].

2. Voznosymenko, D. (2017). Pidhotovka maybutnikh vchyteliv matematyky do realizatsiyi naskriznoyi liniyi klyuchovykh kompetentnostey "Zdorovya i bezpeka". [Preparation of future teachers of mathematics for the implementation of a cross-cutting line of key competencies "Health and Safety"]. Problems of modern teacher training. Uman, Vol.10. pp. 106-112. [in Ukrainian].

3. Voznosymenko, D.A. (2020). Pidhotovka maybutnikh uchyteliv matematyky do zabezpechennya valeolohichnoho suprovodu navchannya uchniv osnovnoyi shkoly [Preparation of future mathematics teachers to provide valeological support for primary school students]. Doctor's thesis. Uman, 376 p. [in Ukrainian].

4. Zhara, G.I. (2009). Pidhotovka maybutnikh uchyteliv do formuvannya $\mathrm{v}$ uchniv valeolohichnykh ponyat na zasadakh mizhpredmetnykh zvyazkiv shkilnykh pryrodnychykh kursiv [Preparation of future teachers for the formation of valeological concepts in students on the basis of interdisciplinary links of school science courses]. Candidate's thesis. Kyiv, 283 p. [in Ukrainian].

5. Knysh, T.V. (2001). Valeolohichna pidhotovka maybutnikh vykhovateliv doshkilnykh zakladiv osvity [Valeological training of future educators of preschool educational institutions]. Candidate's thesis. Lutsk, 211 p. [in Ukrainian].

6. Korobova, I. (2013). Realizatsiya indyvidualnoho pidkhodu do formuvannya metodychnoyi kompetentnosti maybutnikh uchyteliv fizyky [Implementation of an individual approach to the formation of methodological competence of future teachers of physics]. Scientific notes Series: Problems of methods of physical-mathematical and technological education. Kirovohrad. Vol. 4(1). pp. 155-159. [in Ukrainian].

7. Natsionalna doktryna rozvytku osvity: Ukaz Prezydenta Ukrayiny vid 17 kvitnya 2002 roku № 347/2002. [National doctrine of education development: Decree of the President of Ukraine of April 17, 2002 № 347/2002]. 
Available at: htpp://www.kmu.gov.ua/control/uk/publis [in Ukrainian].

8. Onovlennya prohram dlya bazovoyi zahalnoyi serednoyi osvity [Update programs for basic general secondary education]. Available at: https://www.edera.com/mon59/ [in Ukrainian].

9. Osadchenko, T.M. (2017). Pidhotovka maybutnoho vchytelya do stvorennya zdorovyazberezhuvalnoho seredovyshcha pochatkovoyi shkoly [Preparation of the future teacher for creation of the health-preserving environment of elementary school]. Candidate's thesis. Zhytomyr, 251 p.[in Ukrainian].

10. Pyasetska, N.A. (2004). Formuvannya valeolohichnoyi kultury maybutnikh uchyteliv u vyshchykh zakladakh osvity I II rivniv akredytatsiyi
[Formation of valeological culture of future teachers in higher educational institutions of I-II levels of accreditation]. Candidate's thesis. Kyiv, 223 p.[in Ukrainian].

11. Urum, N.S. (2008) Pidhotovka maybutnikh vchyteliv do zabezpechennya zdorovoho sposobu zhyttya molodshykh shkolyariv [Preparation of future teachers to ensure a healthy lifestyle of primary school children]. Candidate's thesis. Kyiv, 213 p. [in Ukrainian].

12. Shcherbyna, I.Yu. (2017). Pedahohichni umovy pidhotovky maybutnikh uchyteliv do zdorovyazberihayuchoho navchannya uchniv u zahalnoosvitniy shkoli [Pedagogical conditions of preparation of future teachers for healthpreserving education of pupils in comprehensive school]. Extended abstract of candidate's thesis. Cherkasy, 20 p. [in Ukrainian].

Стаття надійшла до редакції 22.12.2020

УДК 78.0711.1:782

DOI:

Ірина Дубровіна, кандидат педагогічних наук, доиент, науковий співробітник Відділу музичних фондів Інституту книгознавства НБУВ

\section{ТВОРЧІ ЗВ'ЯЗКИ КАРОЛЯ ШИМАНОВСЬКОГО 3 УКРАЇНОЮ НА ПОЧАТКУ ХХ СТОЛІТТЯ}

У статті розглянуто творчі зв'язки видатного виконавия, композитора Кароля Шимановського з Україною. Наукове вивчення мистецької спадщини Кароля Шимановського стало складовою слов'янської музичної культури та педагогіки, щуо потребує бібліографічних досліджень для збереження спільної культурної пам'яті. Проаналізовано дитячі та юнаџькі роки мития, родинні мистецькі зв'язки і вплив музичного довкілля в Украӥні того часу.

Кароль Шимановський представляє національне мистецтво, де польський характер взаємопроникає у слов'янську ментальність. У його творчості неоренесансного бачення відроджується хорова вокальність як основа професійної польської музики, щзо здійснює контакт між Західною та Східною Церквою, зближує католицизм з православ'ям, щчо є спільною рисою для слов'янського світу того історичного періоду.

Ключові слова: творчі зв'язки; педагог; піаніст; музичний діяч; Кароль Шимановський.

Jim. 10.

Iryna Dubrovina, Ph.D.(Pedagogy), Asossiate Professor, Researcher of the Music Funds Department NLUV Institute of Bibliology

\section{CREATIVE RELATIONS OF THE OUSTANDING PERFORMER, TEACHER KAROL SZYMANOWSKI WITH UKRAINE AT THE BEGINNING OF THE XX CENTURY}

The article considers the creative connections of the outstanding performer, composer with Ukraine. The scientific study of the Karol Szymanowski's artistic heritage has become a component of the Slavic music culture and pedagogy, which requires bibliographic research to preserve common cultural memory. The artist's childhood and adolescence, family artistic ties and influence of the musical environment in Ukraine at that time were analyzed.

Karol Szymanowski represents national art, where the Polish character interpenetrates into the Slavic mentality. Choral vocality as the basis of professional Polish music regenerates in his art of Neo-Renaissance vision, and this makes contact between the Western and Eastern Churches and brings Catholicism closer to Orthodoxy, which is a common feature of the Slavic world of that historical period.

There was studied the role of Ukraine in the artist's work, which the period of forming of the Polish classic as a composer, performer, teacher, publicist was closely connected with. Karol Szymanowski represents national art, where the Polish character interpenetrates into the Slavic mentality. Choral vocality as the basis of professional Polish music regenerates in his art of Neo-Renaissance vision, and this makes contact between the Western and Eastern Churches and brings Catholicism closer to Orthodoxy, which is a common feature of the Slavic world of that historical period. The manuscript proves that forming of the artist's personality took place under the influence of the following significant factors: traditions of musical and cultural life of the village of Tymoshivka with a typical European type of education, music making; a significant role of the talented colleagues in the training and education 